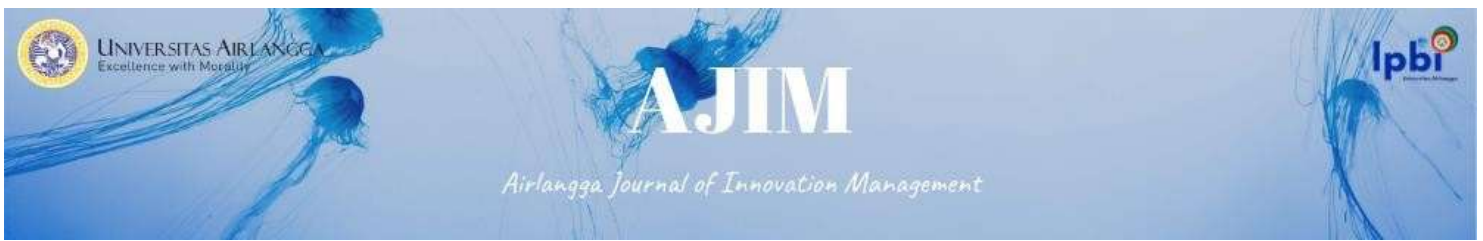

Vol.1, No.2, October 2020

e-ISSN: 2722-5062

DOI: 10.20473/ajim.v1i1.19438

\title{
INOVASI KEUANGAN DI BIDANG EQUITY CROWDFUNDING DALAM PENGEMBANGAN PASAR MODAL
}

\author{
Cynthia Kurniawan Ong \\ Universitas Airlangga \\ E-mail korespondensi: $\underline{\text { c.cynthiakrnwn@gmail.com }}$
}

\begin{abstract}
ABSTRAK
Artikel ini memaparkan gagasan baru tentang teknologi informasi urun dana ekuitas (equity crowdfunding), berdasarkan Undang-Undang Pasar Modal dan peraturan otoritas jasa keuangan. Penelitian ini merupakan penelitian yuridis normatif yaitu mengkaji isu hukum terkait equity crowdfunding dalam perkembangan pasar modal termasuk yang berasal dari aturan yang berkaitan dengan topik dan pendekatan konseptual yaitu pendapat hukum dari para ahli yang diambil dari jurnal, buku, dan sumber terverifikasi lainnya yang terkait dengan topik tersebut). Hasil penelitian menyimpulkan bahwa equity crowdfunding merupakan sistem baru yang penting dalam dunia bisnis oleh karena itu diperlukan payung hukum yang memadai untuk melindungi komunitas pengguna layanan. Meski sudah ada beberapa regulasi hukum terkait urun dana ekuitas, namun belum cukup menjelaskan keterkaitannya dengan pasar modal. Sehingga, aturan hukum teknologi baru informasi harus dijelaskan sedemikian rupa agar tidak menimbulkan kebingungan di kemudian hari dan dapat digunakan untuk perlindungan masyarakat.
\end{abstract}

Kata Kunci: Pasar Modal, Teknologi Keuangan, Urun Dana Ekuitas

\begin{abstract}
This article presents a new idea of equity crowdfunding information technology, based on the Capital Market Law and financial services authority regulations. The research method uses normative juridical approach method including those derived from rules related to the topic and conceptual approaches, namely legal opinions from experts drawn from journals, books and other verified sources related to the topic). The results of the study conclude that equity crowdfunding is an important new system in the business world. Therefore, an adequate legal umbrella is needed to protect the community of service users. Although there are several legal regulations related to equity crowdfunding, they do not adequately explain its relationship to the capital market. Thus, the new information technology law rules must be explained in such a way so as not to cause confusion in the future and can be used for public protection.
\end{abstract}

Keywords: Capital Market, Financial Technology, Equity Crowdfunding

\section{PENDAHULUAN}

Dalam pelaksanaan pembangunan ekonomi nasional suatu negara diperlukan pembiayaan baik dari pemerintah maupun masyarakat, pasar modal sebagai salah satu alternatif pendanaan baik bagi pemerintah ataupun swasta. Pemerintah yang membutuhkan dana dapat menerbitkan obligasi atau surat utang dan menjualnya ke masyarakat melalui pasar modal, dan swasta yaitu perusahaan yang membutuhkan dana dapat menerbitkan efek baik dalam bentuk saham atau obligasi dan menjualnya ke masyarakat melalui pasar modal (Nasution, 2015). 


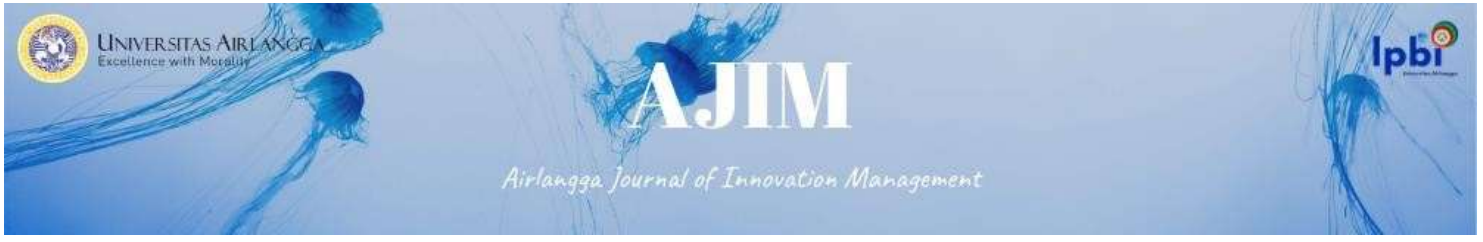

Keberadaan pasar modal di Indonesia menjadi salah satu faktor penting dalam pembangunan perekonomian nasional, bahkan secara faktual pasar modal yang tanggung dan berdaya saing global serta terorganisir dengan baik telah menjadi pusat saraf financial (financial serve centre) pada dunia ekonomi modern dewasa ini. Maka, pasar modal juga dijadikan sebagai salah satu indikator perkembangan perekonomian suatu negara (Muklis, 2016). Suatu perkembangan tidak dapat dilepaskan dari perkembangan teknologi. Di era sekarang ini, perkembangan teknologi berkembang semakin pesat dan cepat. Inovasi kian bermunculan dalam berbagai aspek kehidupan masyarakat, sehingga mendorong berbagai sektor untuk menggunakan teknologi, salah satunya yaitu sektor keuangan yang sering disebut dengan teknologi keuangan atau financial technology (fintech). Hadirnya teknologi keuangan membawa perubahan yang signifikan pada sektor keuangan seperti pada produk keuangan, model bisnis keuangan, atau perangkat lunak yang berkaitan dengan keuangan serta komunikasinya (Gomber dkk, 2017). Dunia bisnis dalam industri sektor keuangan pun menjadi lebih mudah menjangkau pada seluruh lapisan masyarakat, dimana hal tersebut sangat membantu pemerintah dalam meningkatkan pertumbuhan ekonomi.

Salah satu permasalahan ekonomi yang harus ditangani oleh pemerintah adalah kendala permodalan bagi para pelaku usaha. Dalam menghadapi permasalahan demikian maka dibutuhkan sumber dana pembiayaan yang berasal dari lembaga keuangan (Irawati, 2019). Berbagai produk dari financial technology bermunculan dengan produk-produk yang didesain untuk mempermudah masyarakat, salah satunya adalah layanan urun dana melalui penawaran saham berbasis teknologi informasi atau equity crowdfunding sebagai salah satu produk yang memberikan solusi dalam mengatasi kesulitan ekonomi dalam hal permodalan untuk membangun dan mengembangkan usaha (Nugroho \& Rachmaniyah, 2015). Dengan perkembangan financial technology di hampir setiap sektor keuangan, tak terkecuali di sektor pasar modal. Oleh karena itu, tema terkait inovasi keuangan di bidang Equity Crowdfunding dalam perkembangan Hukum Pasar Modal di Indonesia menjadi menarik untuk dibahas lebih mendalam. Sehingga tujuan penelitian ini adalah untuk menganalisis Equity Crowdfunding terangkum dalam aktivitas pasar modal, untuk menganalisis kesamaan Equity Crowdfunding dengan Initial Public Offering dalam pasar modal dan untuk menganalisis peraturan Otoritas Jasa Keuangan dan rencana pengembangan Equity Crowdfunding di Indonesia.

\section{TINJAUAN PUSTAKA}

\section{Pasar Modal}

Berdasarkan pendapat Mas Rahmah, "Pasar modal (capital market) menjadi sumber pembiayaan yang sangat dibutuhkan oleh pelaku usaha yang memerlukan tambahan modal, juga sebagai alternatif pembiayaan bagi masyarakat investor" (Rahmah, 2019). Menurut Alan N.Rechtschaffen sebagaimana dikutip oleh Mas Rahmah, bahwa pasar modal merupakan tempat bertemunya pihak yang memiliki kelebihan kapasitas modal (investor) dengan pihak yang membutuhkan tambahan modal, baik modal jangka pendek maupun jangka panjang (Rahmah, 2019). Berdasarkan Pasal 1 Angka 13 Undang-Undang Nomor 8 Tahun 1995 tentang Pasar Modal (selanjutnya disebut dengan Undang-Undang Pasar Modal), bahwa pasar modal adalah kegiatan yang bersangkutan dengan penawaran umum dan perdagangan Efek, perusahaan publik yang berkaitan dengan Efek yang diterbitkan, serta lembaga dan profesi yang berkaitan dengan Efek. Dari pengertian tersebut maka dapat disimpulkan bahwa dalam pasar modal mempunyai kegiatan yang sama dengan pasar biasa yaitu adanya kegiatan jual beli, tetapi yang membedakan adalah objek yang diperjual- 


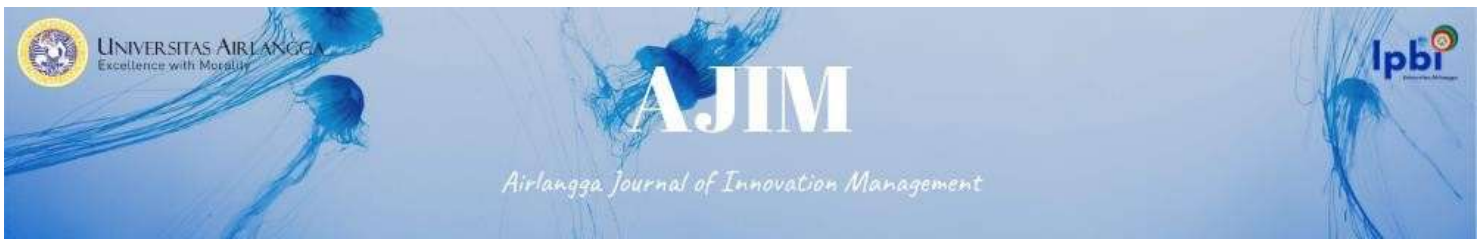

belikan, dalam pasar modal memperjual-belikan Efek. Lebih dari itu, pasar modal memiliki kegiatan yang sangat luas yang meliputi kegiatan yang berkaitan dengan penawaran umum sebagaimana diatur dalam Pasal 1 Angka 15 Undang-Undang Pasar Modal, adalah kegiatan Penawaran Efek yang dilakukan oleh Emiten untuk menjual Efek kepada masyarakat berdasarkan tata cara yang diatur dalam peraturan pasar modal. Sedangkan Emiten dalam Pasal 1 Angka 6 Undang-Undang Pasar Modal sebagai pihak yang melakukan penawaran umum. Emiten dapat berbentuk peseorangan, perusahaan, usaha bersama, asosiasi, atau kelompok yang terorganisasi (Rahmah, 2019).

Pasar modal juga berkaitan dengan kegiatan perusahaan publik, dimana Pasal 1 Angka 8 Undang-Undang Nomor 40 Tahun 2007 tentang Perseroan Terbatas (selanjutnya disebut dengan Undang-Undang Perseroan Terbatas) memberikan definisi Perseroan Publik adalah perseroan yang memenuhi kriteria jumlah pemegang saham dan modal disetor sesuai dengan ketentuan peraturan perundang-undangan di bidang pasar modal. Pasal 1 Angka 22 Undang-Undang Perseroan Terbatas mengatur bahwa perusahaan publik adalah perseroan yang sahamnya telah dimiliki sekurangkurangnya oleh 300 pemegang saham dan memiliki modal disetor sekurang- kurangnya Rp.3.000.000.000 atau suatu jumlah pemegang saham dan modal disetor yang ditetapkan dengan peraturan pemerintah. Suatu perusahaan publik belum tentu dikategorikan sebagai emiten jika belum melakukan penawaran umum, sedangkan emiten dapat dianggap sebagai perusahaan publik apabila jumlah pemegang saham dan modalnya memenuhi ketentuan Pasal 1 Angka 22 Undang-Undang Perseroan Terbatas (Rahmah, 2019).

Serta pasar modal terdapat banyak lembaga atau profesi yang berkaitan dengan Efek baik lembaga yang memberikan bantuan dan kontribusi penting bagi kegiatan penawaran Efek di pasar perdana maupun pada perdagangan Efek di pasar sekunder. Selain itu terdapat juga profesi penunjang yang terdiri dari notaris pasar modal, konsultan hukum pasar modal, penilai, dan akuntan publik, serta terdapat lembaga penunjang pasar modal yang terdiri dari Biro Administrasi Efek, Wali Amanat, dan Kustodian (Rahmah, 2019).

Adapun fungsi pasar modal sebagai berikut (Rahmah, 2019):

1) Fungsi Likuiditas, pasar modal menyediakan dana yang dibutuhkan dengan memfasilitasi transfer modal tidak likuid (modal yang belum diinvestasikan) oleh pihak investor kepada pihak yang membutuhkan modal, yang dilakukan dengan cara menjual Efek seperti saham atau obligasi.

2) Fungsi Pembiayaan, pasar modal menyediakan alternatif pendanaan dan sumber pembiayaan jangka panjang bagi perusahaan yang membutuhkan dengan cara mengerahkan dana dari masyarakat yang membeli instrumen keuangan di pasar modal, dalam hal perushaan tidak memiliki aset berwujud yang cukup untuk memperoleh dana tunai, atau tidak dapat mengakses pembiayaan melalui perbankan karena tidak memenuhi persyaratan.

3) Fungsi Alternatif Investasi, pasar modal menyediakan investasi di bidang properti, emas, valuta asing, dan sebagainya yang memberikan kesempatan kepada investor untuk mendapatkan imbalan investasi sesuai dengan karakteristik instrument investasi yang dipilih.

4) Fungsi Tabungan Publik, melalui public saving masyarakat menyediakan dana likuid yang dapat diakses oleh perusahaan yang membutuhkan, dan dana tersebut digunakan oleh perusahaan untuk kegiatan yang bersifat produktif, sehingga dapat meningkatkan produktivitas nasional karena membantu peningkatan produksi barang dan jasa dalam skala 


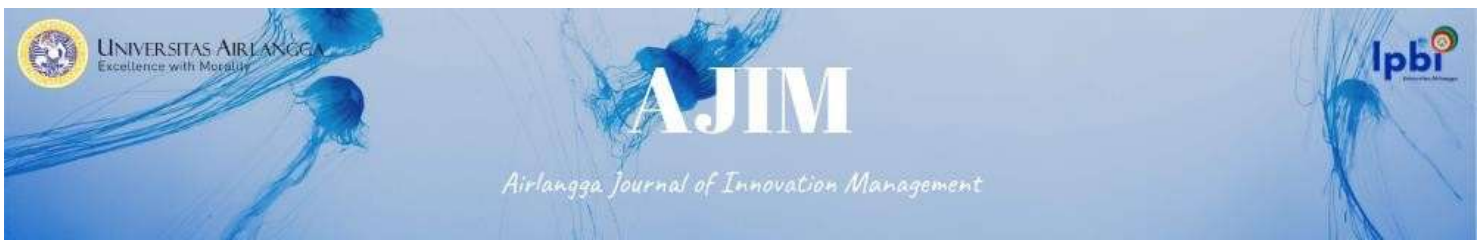

yang lebih besar.

5) Fungsi Distribusi/Pemerataan Pendapatan, investor yang membeli instrumen di pasar modal dapat memperoleh pendapatan berupa dividen dan pendapatan tetap atau bunga karena pasar modal memungkinkan investor untuk menyimpan dan memelihara unit/aset dengan depresiasi dan resiko yang lebih rendah.

6) Fungsi kesejahteraan, pasar modal menyediakan sumber pembiayaan jangka panjang yang dialokasikan dalam bentuk modal untuk menciptakan atau memperluas lapangan kerjam meningkatkan volume aktivitas perekonomian yang sehat, serta memberikan distribusi pendapatan kepada masyarakat.

\section{Equity Crowdfunding}

Urun dana atau Crowdfunding adalah suatu alternatif metode pendanaan usaha yang berkembang pesat dan kian digemari baik di negara maju maupun negara berkembang. Crowdfunding merupakan penggalangan dana dari masyarakat untuk membiayai suatu proyek, pinjaman kepada individual atau bisnis maupun keperluan lain melalui platform berbasis internet (Hutomo, 2019). Menurut Valanciene L dan Jegeleiciute, Crowdfunding adalah sebuah metode untuk menghubungkan antara entrepeneu yang menginginkan peningkatan modal dan investor yang memiliki sumber dana melalui entitas intermediary berbasis internet (Valanciene \& Jegeleiciute, 2014). Crowdfunding merupakan teknik pendanaan untuk proyek atau unit usaha yang melibatkan masyarakat secara luas (Akbar, 2020). Berdasarkan pengertian tersebut dapat disimpulkan bahwa di dalam sistem Crowdfunding terdapat adanya korelasi antara investor yang memiliki sumber dana terhadap mereka yang mempunyai proyek usaha atau mempunyai ide kreatif suatu usaha tertentu yang membutuhkan suntikan dana atau permintaan terhadap financial source (Nugroho \& Rachmaniyah, 2015). Crowdfunding menjadi platform yang dapat diintegrasikan secara praktis di setiap sektor kegiatan ekonomi, salah satunya yaitu di sekotor Usaha Mikro Kecil dan Menengah. Praktek penggalangan dana ini merupakan upaya untuk menghimpun peran atau kontribusi dari masyarakat luas untuk mewujudkan sebuah program atau proyek tertentu yang dilakukan secara online (Kocer, 2014). Sehingga Crowdfunding sebagai platform intermediasi keuangan berbasis internet yang mengumpulkan dana dari masyarakat umum untuk membiayai suatu proyek atau unit usaha dengan menginformasikan proposal suatu proyek (Nugroho \& Rachmaniyah, 2015).

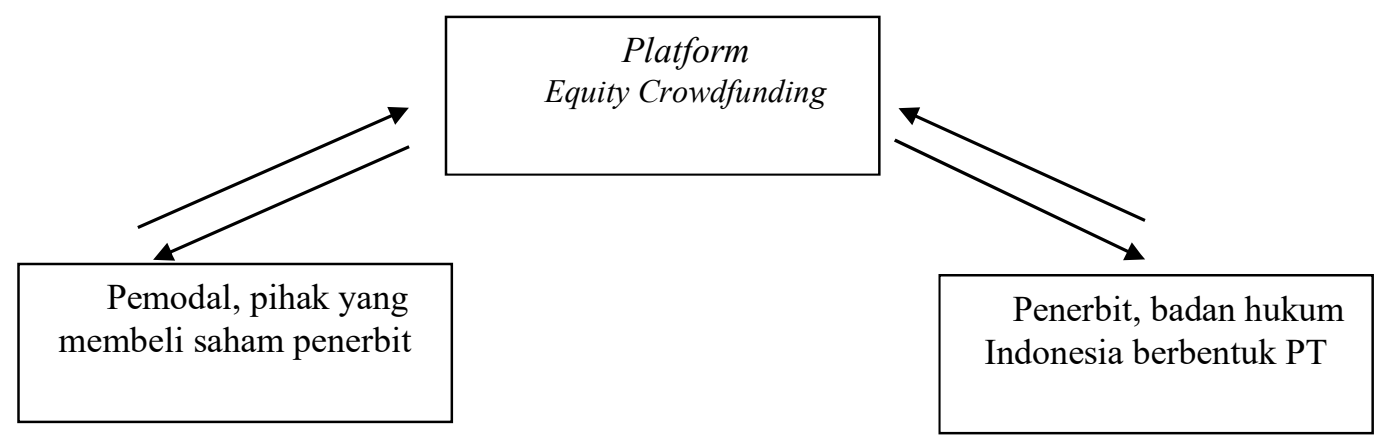

Gambar 1. Proses Equity Crowdfunding Menghimpun Dana Sumber: Penulis (2020) 


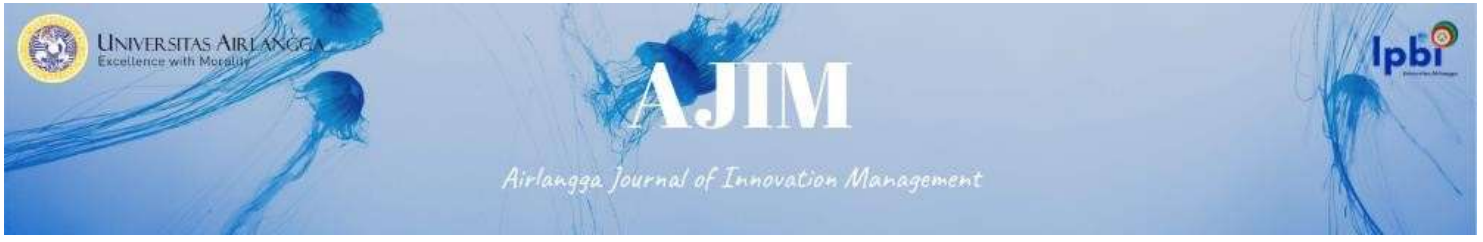

Pada pelaksanaan Equity Crowdfunding terdapat tiga pelaku utama yaitu platform Equity Crowdfunding berperan sebagai intermediasi keuangan yang mencarikan pendanaan kepada crowd investor melalui internet, Penerbit yang membutuhkan modal dengan mengajukan proposal permintaan pendanaan melalui platform Equity Crowdfunding, dan Pemodal melihat dan menganalisis peluang investasi yang ditawarkan pihak Penerbit melalui platform equity crowdfunding, kemudian memberikan komitmennya untuk mendanai program tersebut.

Crowdfunding mempunyai empat model bisnis yaitu :

1) Donation Based, digunakan untuk proyek atau program bersifat non-profit, yang berinisiatif sosial dan amal sehingga para penyandang tidak mengharapkan keuntungan, tetapi umumnya mereka akan memperoleh imbalan dalam bentuk jasa atau barang dari aksi donasi yang mereka lakukan. (Forbes \& Schaefer, 2017). Contohnya membantu penderita kanker yang tidak mempunyai dana.

2) Reward Based, proyek atau program yang memberikan penawaran berupa imbalan barang, jasa atau hak, dalam hal ini bukan memberikan keuntungan dari proyek tersebut, biasanya digunakan untuk program dari industri kreatif seperti games, yang mana para donator akan mendapat imbalan berupa fitur-fitur menarik dari games tersebut. (Nugroho \& Rachmaniyah, 2015).

3) Debt Based, sama seperti pinjaman kredit dimana pihak startup atau UKM sebagai debitur mengajukan proposalnya dan crowd investor sebagai kreditur akan menyetorkan modalnya sebagai pinjaman dengan imbalan berupa bunga.(Hsueh \& Koh, 2015).

4) Equity Based, penyetoran dana crowd investor akan menjadi ekuitas (saham) sebagai kepemilikan atas unit usaha yang diprogramkan oleh startup atau UKM tersebut dan crowd investor mendapatkan imbalan keuntungan dari unit usaha tersebut sesuai dengan persentase penyetoran dana. (Belleflame \& Lambert, 2013).

Dasar hukum crowdfunding diatur dalam beberapa Peraturan Otoritas Jasa Keuangan, yaitu Layanan Pinjam Meminjam Uang Berbasis Teknologi Informasi (selanjutnya disebut dengan POJK 77/2016), Peraturan OJK No.13/POJK.02/2018 tentang Inovasi Keuangan Digital di Sektor Jasa Keuangan (selanjutnya disebut dengan POJK 13/2018) dan Peraturan OJK No.37/POJK.04/2018 tentang Layanan Urun Dana Melalui Penawaran Saham Berbasis Teknologi Informasi (equity crowdfunding) (selanjutnya disebut dengan POJK 37/2018.

\section{METODE PENELITIAN}

Penelitian ini merupakan penelitian yuridis normatif yaitu mengkaji isu hukum terkait equity crowdfunding dalam perkembangan pasar modal. Bahan hukum primer yang digunakan meliputi Undang-Undang (UU) dan Peraturan Otoritas Jasa Keuangan (POJK). Bahan hukum sekunder yang digunakan meliputi buku teks, jurnal ilmiah dan artikel ilmiah di internet. Penulis juga mengakses beberapa website internet yang ada kaitannya dengan topic penelitian guna mendapatkan kerangka konsep berpikir dan memahami konteks dari penelitian secara mendalam. Bahan hukum primer dan sekunder kemudian dianalisa untuk mencari keterkaitan dan kesesuaian dengan topik penelitian.

Metode penelitian yang digunakan dalam penelitian ini meliputi pendekatan undang- undang (statue approach) dan pendekatan konseptual (conceptual approach). Pendekatan undang-undang (statue approach) dilakukan dengan menelaah semua undang-undang dan regulasi yang bersangkut paut dengan isu hukum yang sedang ditangani. Pendekatan konseptual (conceptual approach) beranjak dari pandangan-pandangan dan doktrin-doktrin yang berkembang di dalam ilmu hukum. 


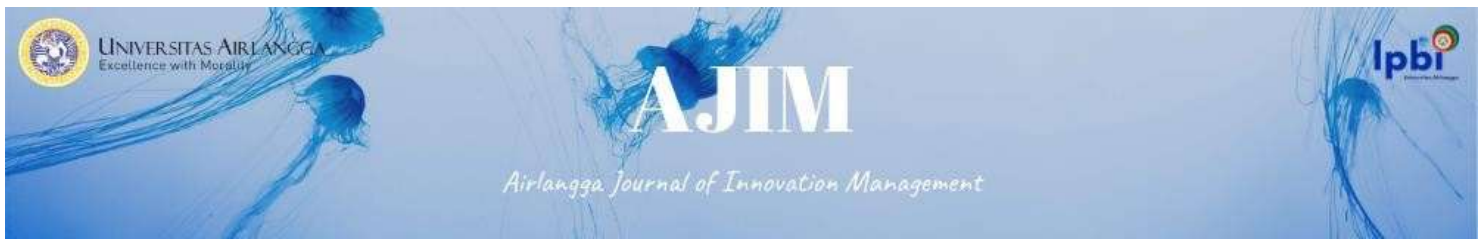

\section{PEMBAHASAN}

\section{Equity Crowdfunding Dalam Perkembangan Hukum Pasar Modal}

Berdasarkan Undang-Undang Pasar Modal terlihat bahwa adanya pembatasan sempit terhadap definisi pasar modal, seolah yang menjadi fokus utama dalam pasar modal adalah kegiatan penawaran umum. Menurut pendapat Munir Fuady sebagaimana dikutip pada jurnal Naomi Norita dan Deborah Harahap, pasar modal adalah suatu tempat atau sistem dipenuhinya kebutuhan-kebutuhan dana untuk capital suatu perusahaan, merupakan pasar tempat orang membeli dan menjual surat Efek yang baru dikeluarkan (Norita \& Harahap, 2020). Sedangkan menurut Victor Purba dikutip oleh sumber yang sama, pasar modal adalah suatu lembaga dimana dana-dana jangka panjang baik utang maupun modal sendiri diperdagangkan. Oleh sebab itu, tempat dilakukannya perdagangan Efek seharusnya tidak hanya mengacu kepada kegiatan penawaran umum sebagaimana yang diatur dalam Undang-Undang Pasar Modal.

Berdasarkan Pasal 6 huruf b Undang-Undang Nomor 21 Tahun 2011 tentang Otoritas Jasa Keuangan (selanjutnya disebut Undang-Undang OJK), menyatakan bahwa "OJK melaksanakan tugas pengaturan dan pengawasan terhadap kegiatan jasa keuangan di sektor Pasar Modal”. Definisi pasar modal juga diatur secara sempit dan mengacu pada ketentuan Undang-Undang Pasar Modal. Tetapi ketika diterbitkannya POJK 37/2018, berdasarkan Pasal 4 menyatakan bahwa "Kegiatan Layanan Urun Dana sebagaimana dimaksud dalam Peraturan Otoritas Jasa Keuangan ini merupakan kegiatan jasa keuangan di sektor pasar modal". Hal tersebut menjadi kontradiksi karena dalam UndangUndang Pasar Modal dan Undang-Undang OJK, kegiatan equity crowdfunding tidak masuk dalam definisi pasar modal.

Equity crowdfunding berada dalam lingkup kegiatan perdagangan Efek yaitu saham menggunakan sistem elektronik untuk mempertemukan kepentingan pemodal dan penerbit. Pihak penyelenggara/platform menyediakan jalan bagi perusahaan penerbit saham agar dapat mengumpulkan dana dari pemodal untuk kepentingan bisnisnya. Pemodal menerima ekuitas sebagai imbalan dari dana mereka, dan ketika mereka membeli ekuitas atau saham yang ada, hukum Efek atau pasar modal mengatur transaksi tersebut. (Darian, 2020).

Pada dasarnya kegiatan equity crowdfunding merupakan bentuk Mini Initial Public Offering (Mini IPO) (Economic Times, 2020). Mini IPO berfungsi agar usaha kecil dan menengah maupun startup tidak perlu memperoleh perizinan untuk dapat memperoleh dana dari masyarakat, sehingga membuka kesempatan bagi para perusahaan pemula untuk mengumpulkan dana tidak hanya terbatas pada pemodal yang terakreditasi tetapi juga dari pemodal yang tertarik untuk mendanai perusahaan baru yang mereka dukung (Norita \& Harahap, 2020)

Syarat total dana yang dihimpun melalui penawaran saham oleh penerbit berdasarkan Pasal 5 POJK 37/2018 adalah maksimal Rp.10.000.000.000,00 (sepuluh miliar rupiah), dan bagi penerbit yaitu perseroan terbatas, berdasarkan Pasal 34 POJK 37/2018 bukan merupakan perusahaan terbuka atau anak perusahaan terbuka dan tidak memiliki kekayaan melebihi Rp.10.000.000.000,00 (sepuluh miliar rupiah), tidak termasuk tanah dan bangunan. Berbeda di pasar modal, dalam hal penawaran umum, contohnya untuk melakukan pencatatan di pasar utama, laporan keuangan audit perusahaan tgerakhir memiliki kekayaan bersih minimal Rp.100.000.000,00 dan sudah melakukan kegiatan operasional minimal 36 bulan. (BEI, 2018).

Dengan adanya kegiatan equity crowdfunding ditujukan agar dapat meningkatkan industri tersebut sebagai layanan penyediaan modal usaha bagi usaha kecil dan menengah maupun startup. 


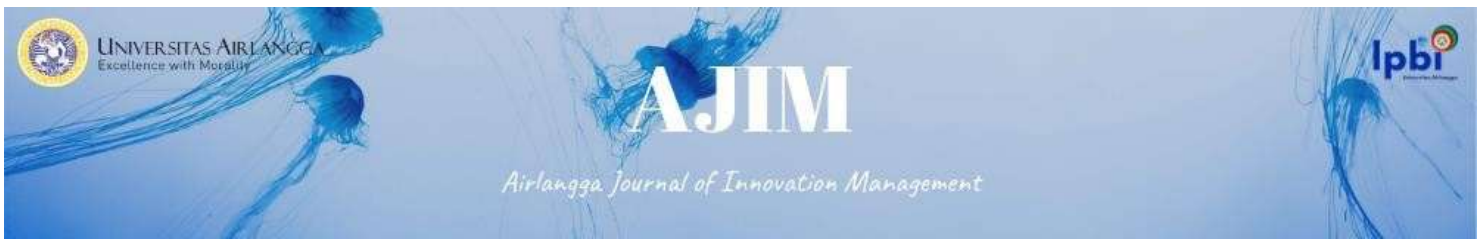

Equity crowdfunding memberikan konsep baru terkait kegiatan penawaran saham dan secara filosofi merupakan bagian dari pasar modal, sehingga kegiatan equity crowdfunding mempunyai hakikat dari pasar modal itu sendiri. (Norita \& Harahap, 2020). Dapat terlihat bahwa kegiatan equity crowdfunding juga sama dengan kegiatan pasar modal dalam hal perdagangan Efek yaitu saham. Berdasarkan POJK 37/2018 pun diatur equity crowdfunding termasuk sebagai kegiatan jasa keuangan dalam sektor pasar modal.

Mekanisme layanannya pun mempunyai banyak kesamaan dengan penawaran umum dalam pasar modal, hanya saja penyelenggaraannya lebih sederhana baik secara kelembagaan, orientasi modal yang dihimpun, dan subjek penerima modal atau penerbit. Berdasarkan Pasal 1 angka 7 POJK 37/2018 menyatakan bahwa "penerbit adalah badan hukum Indonesia berbentuk perseroan terbatas yang melakukan penjualan sahamnya melalui Penyelenggaraan Layanan Urun Dana", kemudian Pasal 4 POJK/2018 menentukan "penerbit bukan merupakan Perusahaan Publik sebagaimana dimaksud dalam Undang-Undang Pasar Modal, yaitu jumlah pemegang saham penerbit tidak lebih dari 300 pihak dan jumlah modal disetor penerbit tidak lebih dari Rp.18.000.000.000,00 (delapan belas miliar rupiah). Dalam hal ini pemilik equity crowdfunding atau penyelenggara layanan urun dana melalui penawaran saham berperan sebagai penjamin emisi efek. Penerbit bersama dengan penyelenggara dapat bersepakat dalam menentukan jumlah minimum dana yang harus diperoleh dalam penawaran saham melalui equity crowdfunding, serta berbeda dengan perjanjian penjaminan emisi Efek dalam penawaran perdana, penyelenggara sebagai penjamin emisi Efek tidak memiliki pilihan tapi menjalankan fungsinya dengan komitmen penuh terhadap jumlah minimum dana yang harus diperoleh (Hutomo, 2020). Apabila terdapat perusahaan yang telah berhasil memperoleh dana dari equity crowdfunding dan berniat untuk masuk ke bursa, hal tersebut tidak menjadi masalah, dan perusahaan selanjutnya akan mengikuti ketentuan bursa (Hilmi, 2020). Sehingga antara equity crowdfunding yang diatur oleh POJK 37/2018 dan penjualan di bursa berdasarkan Undang-Undang Pasar Modal dapat saling melengkapi.

\section{Equity Crowdfunding dan Initial Public Offering}

Pada dasarnya equity crowdfunding memiliki persamaan dengan IPO, yaitu:

1. Merupakan sumber pembiayaan degan menjual saham (ekuitas) perusahaan sesuai dengan Pasal 1 angka 1 POJK 37/2018 bahwa equity crowdfunding adalah penyelenggaraan layanan penawaran saham yang dilakukan oleh penerbit untuk menjual saham secara langsung kepada pemodal;

2. Mentaati prinsip keterbukaan informasi tentang keadaan keuangan dalam bentuk financial report (laporan keuangan) dan laporan penggunaan dana hasil penawaran saham, sesuai dengan Pasal 35 POJK 37/2018 bahwa penerbit harus menyerahkan dokumen dan/atau informasi kepada penyelenggara paling sedikit mengenai laporan keuangan, dan Pasal 39 POJK 37/2018 bahwa penerbit wajib menyampaikan laporan tahunan yang memuat pula informasi tentang realisasi penggunaan dana hasil penawaran saham melalui Layanan Urun Dana;

3. Melakukan pencatatan informasi pemegang saham (pemodal/investor) di kustodian, sebagaimana dalam Pasal 38 POJK 37/2018 bahwa penerbit wajib mencatatkan sahamnya di kustodian yang disepakati oleh penyelenggara dan penerbit.

Akan tetapi, antara equity crowdfunding dan IPO terdapat perbedaan yang substansial antara lain: 


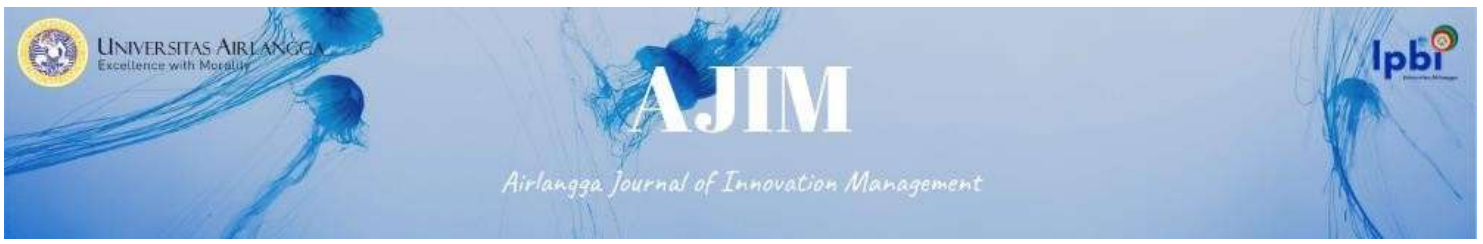

1) Istilah yang berbeda trehadap para pihak, pada Undang-Undang Pasar Modal, pasal 1 angka 4 pihak yang menyelenggarakan sistem untuk mempertemukan penawaran jual beli Efek disebut Bursa Efek, pasal 1 angka 5 perusahaan yang melakukan penjualan saham melalui IPO disebut emiten, sedangkan berdasarkan POJK 37/2018, Pasal 1 angka pihak yang menyelenggarakan layanan urun dana disebut penyelenggara, Pasal 1 angka 6 perusahaan yang melakukan penjualan saham melalui equity crowdfunding disebut penerbit, Pasal 1 angka 7 pihak yang melakukan pembelian saham melalui equity crowdfunding disebut Pemodal.

2) Biaya modal sebagai ketentuan yang harus dipenuhi oleh emiten atau penerbit, berdasarkan pasal 1 angka 22 menentukan emiten memiliki sekurang-kurangnya 300 pemegang saham dan memiliki odal disetor sekurang-kurangnya Rp.3.000.000.000,00 (tiga miliar rupiah) atau suatu jumlah pemegang saham dan modal disetor yang ditetapkan dengan peraturan pemerintah. Sedangkan penerbit bukan merupakan perusahaan dengan struktur kompleks dan bukan merupakan perusahaan terbuka, dengan kekayaan yang tidak lebih dari Rp.10.000.000.000,00 (sepuluh miliar rupiah) tidak termasuk tanah dan bangunan sesuai dengan ketentuan Pasal 34 ayat (1).

3) Jenis perusahaan berbeda sehingga mengakibatkan tunduk pada ketentuan peraturan perundang-undangan yang berbeda, emiten merupakan perseroan terbatas terbuka sebagaimana ditentukan dalam Pasal 1 angka 20 Undang-Undang Pasar Modal, sehingga tidak hanya tunduk pada ketentuan Undang-Undang Perseroan Terbatas, tetapi juga tunduk pada Undang-Undang Pasar Modal, sementara penerbit berdasarkan Pasal 34 ayat (1) huruf b POJK 37/2018 bukan merupakan perusahaan terbuka atau anak perusahaan terbuka sehingga hanya tunduk pada Undang-Undang Perseroan Terbatas saja.

4) Penawaran saham berbeda, Penawaran Umum IPO sebagaimana dimaksud dalam UndnagUndang Pasar Modal, sedangkan penawaran saham berdasarkan Pasal 5 POJK 37/2018 penawaran saham oleh setiap penerbit melalui layanan urun dana bukan merupakan penawaran umum sebagaimana dimaksud dalam Undang-undang Pasar Modal dimana penawaran saham dilakukan melalui penyelenggara yang telah memperoleh izin dari OJK, penawaran saham dilakukan dalam jangka waktu paling lama 12 bulan, dan total dana yang dihimpun melalui penawaran saham paling banyak Rp. 10.000.000.000,00 (sepuluh miliar rupiah).

5) Proses dan keterlibatan lembaga-lembaga penunjang, IPO merupakan proses yang membutuhkan tenggang waktu karena harus dipenuhinya persyaratan baik legal, finansial dan administratif, juga melibatkan setidaknya lembaga penunjang pasar modal berdasarkan Pasal 64 ayat (1) Undang-Undang Pasar Modal yaitu akuntan, konsultan hukum, penilai, notaris, dan profesi lain yang ditetapkan dengan Peraturan Pemerintah. Serta ketika penawaran saham didaftarkan di bursa Efek, maka bertambahnya Lembaga Kliring dan Penjaminan, Lembaga Penyimpanan dan Penyelesaian, Penasihat Investasi dan Biro Administrasi Efek. Sedangkan proses pelaksanaan equity crowdfunding lebih sederhana yaitu melibatkan langsung penerbit, pemodal dan penyelenggara.

6) Kesederhanaan tersebut menjadikan equity crowdfunding sebagai solusi sumber pembiayaan yang praktis dan biaya ringan dibandingkan dengan IPO.

7) Disclosure, prinsip keterbukaan informasi sama-sama harus diterapkan baik pada IPO maupun equity crowdfunding, hanya saja bedanya adalah ketentuan persyaratan penyajian informasi, yaitu pada IPO keterbukaan informasi tersebut terselenggara dengan suatu format yang diatur oleh undang-undang, dalam hal ini Pasal 71 Undang- Undang Pasar Modal menyatakan bahwa "tidak satu pihak pun dapat menjual Efek dalam penawaran umum, kecuali pembeli atau pemesan menyatakan dalam formulir pemesanan Efek bahwa pembeli atau pemesan telah menerima atau memperoleh 


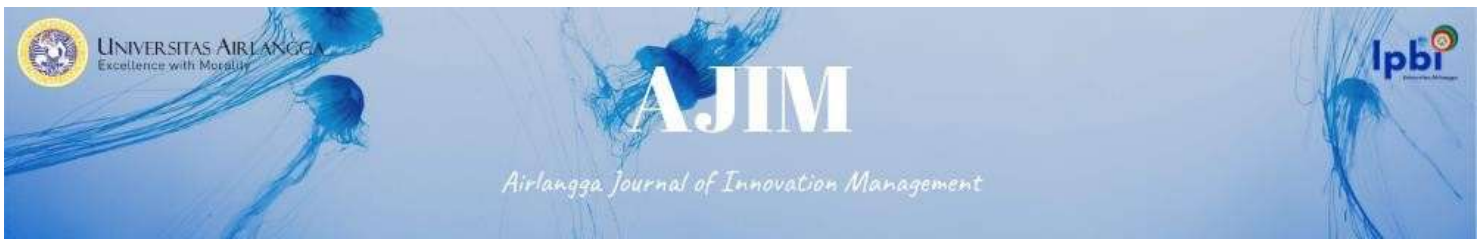

kesempatan untuk membaca Prospektus berkenaan dengan Efek yang bersangkutan sebelum atau pada saat pemesanan dilaksanakan", serta penjelasan Pasal 78 ayat (1) bahwa Prospektus merupakan salah satu dokumen pokok dalam rangka Penawaran Umum, sehingga informasi yang terkandung di dalamnya wajib memuat hal-hal yang sesungguhnya menggambarkan keadaan emiten yang bersangkutan sehingga keterangan atau informasi dapat dijadikan sebagai dasar pertimbangan bagi pihak pemodal untuk menetapkan keputusan investasinya.

Apabila informasi yang disajikan tidak benar tentang fakta materiil atau tidak mengungkapkan informasi yang benar, maka hal tersebut dapat mengakibatkan pemodal mengambil keputusan investasi yang tidak tepat. Sedangkan ketentuan penyajian informasi bagi penerbit dalam equity crowdfunding tidak ditentukan secara khusus, namun pada umumnya penyelenggara akan memperkenalkan penerbit dengan menjelaskan tentang latar belakang baik kapasitas, prestasi hingga tujuan penawaran saham melalui equity crowdfunding guna menarik minat pemodal. Selanjutnya prinsip disclosure diterapkan lebih sederhana pada penerbit dalam bentuk laporan tahunan yang mana memang telah menjadi kewajiban perseroan sebagaimana ditentukan dalam Undang-Undang Perseroan Terbatas bahwa perusahaan wajib membuat laporan keuangan serta laporan pertanggungjawaban direksi kepada pemegang saham di setiap akhir periode tahun pembukuan. (Hutomo, 2020).Berdasarkan penjelasan di atas, sehingga dapat dilihat bahwa meskipun pada prinsipnya equity crowdfunding dan IPO memiliki persamaan dasar, tetapi dalam pelaksanaan teknis sangat banyak perbedaan yang signifikan, dimana memang tujuan dari equity crowdfunding untuk mempermudah proses jual beli saham karena menargetkan kepada pihak-pihak di bawah dari target dalam IPO, seperti startup atau UKM.

\section{Equity Crowdfunding Dalam Peraturan Otoritas Jasa Keuangan dan Rencana Pengembangan}

Perkembangan financial technology dalam masyarakat saat ini tentunya memerlukan payung hukum agar dapat mengimbangi kegiatan masyarakat agar tercipta kepastian hukum dan keadilan. Khususnya apabila terkait jasa di bidang keuangan yang menjadi suatu bisnis yang sangat rentan terhadap berbagai tindakan-tindakan yang merugikan oleh pihak yang tidak bertanggungjawab dengan memanfaatkan keberadaan teknologi yang lebih cepat berkembang sehingga dapat mengakibatkan kerugian bagi para pengguna layanan tersebut (Pranita \& Suardana, 2019). OJK sebagai lembaga negara yang berfungsi melakukan pengawasan dan pengaturan di sektor jasa keuangan segera mengambil langkah dengan menerbitkan aturan hukum terkait inovasi keuangan di bidang teknologi dalam POJK 77/2016 serta terdapat dalam Surat Edaran Otoritas Jasa Keuangan Nomor 2/SEOJK.07/2014 tentang Pelayanan dan Penyelesaian Pengaduan Konsumen Pada Pelaku Usaha Jasa Keuangan (Pramana, 2018)

Berdasarkan Pasal 1 angka 3 POJK 77/2016 menyatakan bahwa "yang dimaksud dengan Layanan Pinjam Meminjam Berbasis Teknologi Informasi merupakan penyelenggaraan layanan jasa keuangan untuk mempertemukan pemberi pinjaman dengan penerima pinjaman dalam rangka melakukan perjanjian pinjam meminjam dalam mata uang rupiah secara langsung melalui sistem elektronik dengan menggunakan jaringan internet". Bentuk perlindungan yang diberikan oleh OJK yaitu apabila terdapat tindakan-tindakan yang melanggar dan mengakibatkan kerugian maka OJK akan meminta untuk menghentikan kegiatan usahanya tersebut, serta akan melakukan pembelaan hukum kepentingan masyarakat sebagai konsumen yang berupa pengajuan gugatan di pengadilan terhadap para pihak yang mengakibatkan kerugian tersebut (Pranita \& Suardana, 2018).

Selanjutnya OJK mengeluarkan peraturan dalam POJK 13/2018 dan yang lebih spesifik 


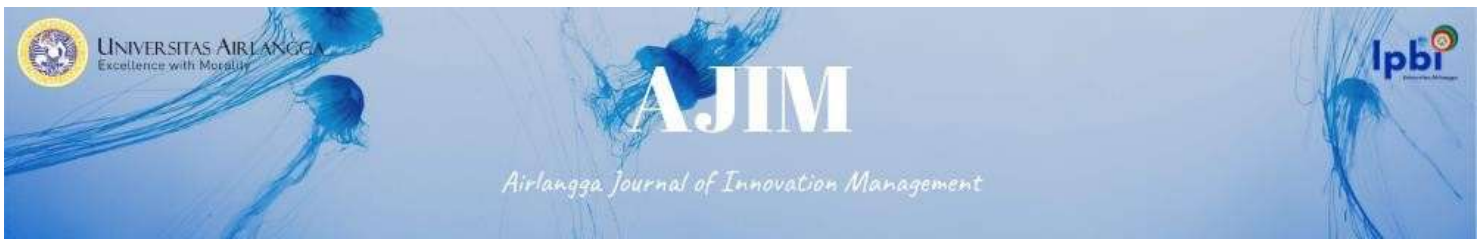

mengatur mengenai equity crowdfunding dalam POJK 37/2018 yang menjadi acuan para pihak dalam melakukan kegiatan financial technology di bidang equity crowdfunding. Dalam bagian menimbang POJK 37/2018 menyatakan bahwa OJK perlu mendukung pelaku usaha pemula (start up company) untuk berkontribusi terhadap perekonomian nasional melalui penyediaan rnatif sumber pendanaan berbasis teknologi informasi. Sehingga dapat terlihat bahwa OJK ingin menjangkau masyarakat usaha-usaha pemula kecil dan menengah dalam pembiayaan berbasis teknologi melalui equity crowdfunding. Sehingga sebagai usaha kecil dan menengah tetap memiliki kesempatan untuk pengembangan modal usaha dengan menawarkan saham dalam platform equity crowdfunding yang telah disediakan oleh perusahaan penyelenggara, tetapi dengan memenuhi syarat yang telah ditentukan oleh OJK dalam POJK.

Beberapa ketentuan syarat yang harus dipenuhi oleh para pemilik usaha kecil dan menengah atau penerbit adalah sebagaimana yang diatur dalam Pasal 6 POJK 37/2018 bahwa Penerbit adalah badan hukum Indonesia berbentuk perseroan terbatas yang menawarkan saham melalui Penyelenggara, berarti apabila para pemilik usaha kecil dan menengah ingin memanfaatkan platform equity crowdfunding dalam pengembangan modalnya maka mereka harus merupakan badan usaha berbentuk badan hukum. Penerbit juga harus berbentuk perseroan terbatas sebagaimana yang ditentukan dalam Pasal 33 POJK 37/2018, dan lebih lanjut dalam Pasal 34 bahwa perseroan terbatas tersebut bukan merupakan perusahaan terbuka atau anak perusahaan terbuka, dimana peraturan ini semakin memudahkan bagi pelaku usaha kecil dan menengah dalam mendapat tambahan modal usaha melalui equity crowdfunding, serta perusahaan tidak memiliki kekayaan melebihi Rp.10.000.000.000,00 (sepuluh miliar rupiah), tidak termasuk tanah dan bangunan. Sehingga para pelaku usaha kecil dan menengah wajib terlebih dahulu mendirikan badan usaha perseroan terbatas secara sah.

Dengan adanya financial technology berupa equity crowdfunding yang diakomodasi dalam POJK 37/2018 maka dapat dijadikan sebagai salah satu sarana bagi para pelaku usaha untuk mendapatkan modal dalam mempertahankan dan meningkatkan usaha mereka. Dengan melakukan penawaran saham melalui platform equity crowdfunding maka para pelaku usaha kecil dan menengah mempunyai kesempatan untuk mendapatkan tambahan modal dari investor atau pemodal sama seperti instrument dalam pasar modal yaitu mereka akan menerima pembagian dividen saat perusahaan mendapatkan laba dan memiliki hak dalam Rapat Umum Pemegang Saham (RUPS) perusahaan (Irawati. 2019)

Selain memberikan perlindungan dan sebagai sarana yang lebih memberikan kemudahan bagi para penerbit, POJK juga memberikan perlindungan bagi pemodal. Mengutip dari Kuti, Bedo, \& Geiszl, "social networks and online platforms create new opportunities to raise funds for business and enable non-professional investors to place their funds without the use of financial intermediary system" (Kuti dkk, 2017). Bahwa dengan adanya platform equity crowdfunding maka dapat menciptakan peluang baru untuk mengumpulkan dana dalam kegiatan bisnis serta memungkinkan investor non-profesional untuk memasukkan modal tanpa perantara sistem keuangan (Irawati, 2019).

Berdasarkan Pasal 42 POJK 37/2018 pemodal yang bukan merupakan badan hukum dan pihak yang mempunyai pengalaman di pasar modal yang dibuktikan dengan kepemilikan rekening Efek minimal 2 tahun sebelum penawaran saham, maka harus memenuhi kriteria penghasilan minimal Rp.500.000.000,00 (lima ratus juta rupiah) per tahun, dapat membeli saham melalui platform equity crowdfunding maksimal 5\% dari penghasilan per tahun, dan penghasilan di atas Rp.500.000.000,00 (lima ratus juta rupiah) dapat membeli saham maksimal 10\% dari penghasilan per tahun. 


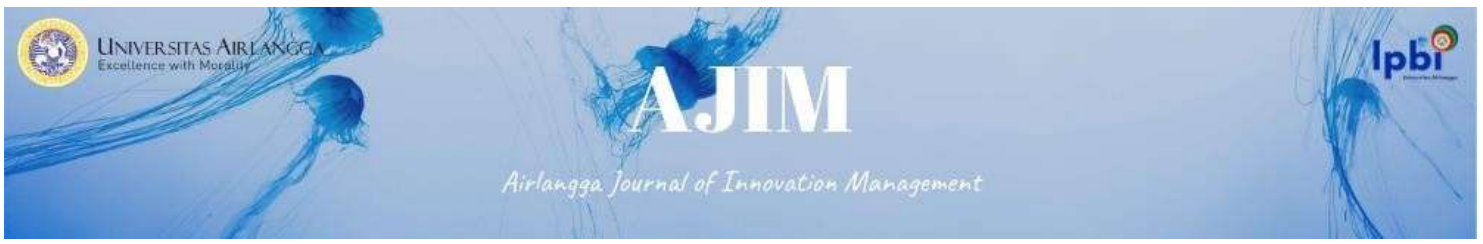

Dalam Pasal 35 POJK 37/2018 mengakomodir perlindungan yang dapat diberikan kepada pemodal diantaranya mewajibkan penerbit untuk menyerahkan dokumen atau menginformasikan risiko utama yang dihadapi penerbit dan risiko kemungkinan tidak likuidnya saham yang ditawarkan jika terdapat risiko kemungkinan tidak likuidnya saham, sehingga diharapkan pemodal telah mendapatkan informasi yang jelas mengenai saham yang akan dibeli untuk menghindarkan kerugian yang tidak diketahui oleh pemodal, karena dengan membaca dan menyetujui dokumen dari penerbit maka pemodal telah mengetahui risiko yang dapat terjadi di kemudian hari ketika berbisnis dengan pemodal.

OJK telah melalui POJK 37/2018 mengeluarkan peraturan dalam berbisnis melalui equity crowdfunding yang di dalamnya terdapat poin-poin penting dalam rangka memberikan perlindungan kepada investor. Sebagai lembaga negara yang memiliki kewenangan untuk memberikan izin kepada penyelenggara financial technology, maka OJK menerapkan adanya Regulatory Sandbox bagi setiap perusahaan penyelenggara yang ingin melakukan pendaftaran perizinan, sehingga melalui Regulatory Sandbox OJK akan melakukan pengujian terhadap perusahaan financial technology apakah layak atau tidak diberikan izin. Regulatory Sandbox berdasarkan Pasal 1 angka 4 POJK 13/2018 adalah mekanisme pengujian yang dilakukan oleh OOJK untuk menilai keandalan proses bisnis, model bisnis, instrument keuangan, dan tata kelola penyelenggara, dengan tujuan memastikan layanan financial technology yang diberikan aman bagi masyarakat. Sehingga dengan adanya Regulatory Sandbox, peran OJK semakin kuat dalam mencegah adanya penyelenggaraan financial technology yang dapat merugikan penggunanya.

\section{KESIMPULAN DAN SARAN}

Dengan perkembangan financial technology khususnya equity crowdfunding yang demikian pesat dalam kehidupan masyarakat saat ini sehingga perlu payung hukum untuk memberikan perlindungan dalam kepastian hukum dan keadilan. Akan tetapi meskipun dalam Pasal 4 POJK 37/2018 menyebutkan bahwa "Kegiatan Layanan Urun Dana sebagaimana dimaksud dalam Peraturan Otoritas Jasa Keuangan ini merupakan kegiatan jasa keuangan di sektor pasar modal”. Hal tersebut menjadi kontradiksi karena dalam Undang-Undang Pasar Modal dan Undang-Undang OJK, kegiatan equity crowdfunding tidak masuk dalam definisi pasar modal karena Undang-Undang Pasar Modal masih mendefinisikan pasar modal secara sempit, padahal equity crowdfunding mempunyai hakikat kegiatan pasar modal khususnya dengan disebutnya equity crowdfunding sebagai Mini IPO bagi usaha kecil dan menengah atau startup sehingga dengan equity crowdfunding maka dapat menjangkau ke lapisan masyarakat yang tidak terjangkau oleh pasar modal. Dalam hal ini, equity crowdfunding menjadi bukti adanya perkembangan dari konsep kegiatan pasar modal.

Meskipun pada prinsipnya equity crowdfunding dan IPO pasar modal memiliki persamaan dasar, tetapi dalam pelaksanaan teknis sangat banyak perbedaan yang signifikan, dimana memang tujuan dari equity crowdfunding untuk mempermudah proses jual beli saham karena menargetkan kepada pihak-pihak di bawah dari target dalam IPO, seperti startup atau usaha kecil dan menengah.

Dengan adanya equity crowdfunding maka dapat dijadikan sebagai salah satu sarana bagi para pelaku usaha untuk mendapatkan modal dalam mempertahankan dan meningkatkan usaha mereka. Dengan melakukan penawaran saham melalui platform equity crowdfunding maka para pelaku usaha kecil dan menengah mempunyai kesempatan untuk mendapatkan tambahan modal dari investor atau pemodal sama seperti instrumen dalam pasar modal, demikian juga dengan investor lebih diberikan kemudahan, karena platform equity crowdfunding merupakan tempat terbuka yang tidak hanya dapat 


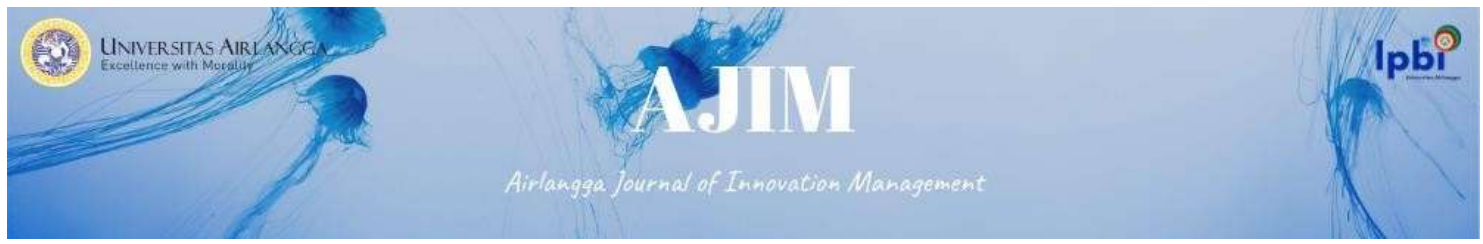

diakses oleh investor yang telah terakreditasi saja, serta proses yang lebih efektif dan efisien dengan keamanan perlindungan yang diberikan oleh POJK. Hukum sebagai payung hukum dalam kehidupan sosial sehingga selalu berkembang mengikuti masyarakat, maka dengan adanya perkembangan financial technology jenis equity crowdfunding, maka sebaiknya Undang-Undang Pasar Modal diperbaharui menyesuaikan dengan POJK sehingga dapat menaungi kegiatan equity crowdfunding.

\section{DAFTAR PUSTAKA}

Akbar, D.S.F. Konsep Crowdfunding untuk Pendanaan Infrastruktur di Indonesia, diakses pada tanggal 18 Mei 2020, https://www.kemenkeu.go.id/publikasi/artikel-dan-opini/konsepcrowdfunding-untuk-pendanaan-infrastruktur-di-indonesia.

Bellefllamme, P., T. Lambert, and A. S. (2013) Individual Crowdfunding Practices. An International Journal of Entrepreneurial Finance, 15, pp.313-333.

Darian M. Ibrahim. Equity Crowdfunding: A Market for Lemons?. Retrieved May 18, 2020, from http://www.minnesotalawreview.org/wp-content/uploads/2016/01/Ibrahim_4fmt.pdf.

Economic Times. What Is Mini-ipo And Why It Costs A Bomb To Lose This Opportunity? Retrieved May 18, 2020, from https://economictimes.indiatimes.com/tech/software/what-is- mini-ipoand-why-it-costs-a-bomb-to-lose-this-opportunity/articleshow/65037586.cms.

Fakhri Hilmi, Deputi Komisioner Pengawas Pasar Modal II OJK, Equity Crowdfunding Tak Saingi Bursa Saham, dikutip pada tanggal 18 Mei 2020, https://investor.id/market-andcorporate/equity-crowd-funding-tak-saingi-bursa-saham.

Forbes, H., \& Schaefer, D. (2017) Guidelines for Successful Crowdfunding. Retrieved May 18, 2020, from https://researchportal.bath.ac.uk/en/publications/guidelinesfor-successfulcrowdfunding.

Gomber, P., Koch, J.-A. and Siering, M. (2017) Digital Finance and FinTech: current research and future research directions, Journal of Business Economics. Springer Berlin Heidelberg, $87(5)$, pp. 537-580.

Hsueh, S.-C., \& Kuo, C.-H. (2017) Effective Matching for P2P Lending by Mining Strong Association Rules. In Proceedings of the 3rd International Conference on Industrial and Business Engineering - ICIBE 2017. New York, USA: ACM Press. pp.30-33.

Hutomo, C.I. (2019) Layanan Urun Dana Melalui Penawaran Saham Berbasis Teknologi Informasi (Equity Crowdfunding). Jurnal Perspektif, 24(2), pp.65-74.

Indonesia, Lampiran I Keputusan Direksi Bursa Efek Indonesia tentang Perubahan Peraturan No. I-A tentang Pencatatan Saham dan Efek Bersifat Ekuitas selain Saham yang diterbitkan oleh Perusahaan Tercatat, Lampiran I Keputusan Direksi PT BEI No. KEP-00183/BEI/12-2018.

Irawati. (2019) Tinjauan Yuridis Pemanfaatan Equity Crowdfunding Bagi Pengembangan Usaha Kecil dan Menengah di Indonesia. Jurnal Diponegoro Law Review, 4(2), pp.1-14

Kocer, S. (2014) Sosial Business in Online Financing: Crowdfunding Narrative of Independent Documentary Producer in Turkey. SAGE, 17(2), 231-248. Retrieved 18 May 2020, from 


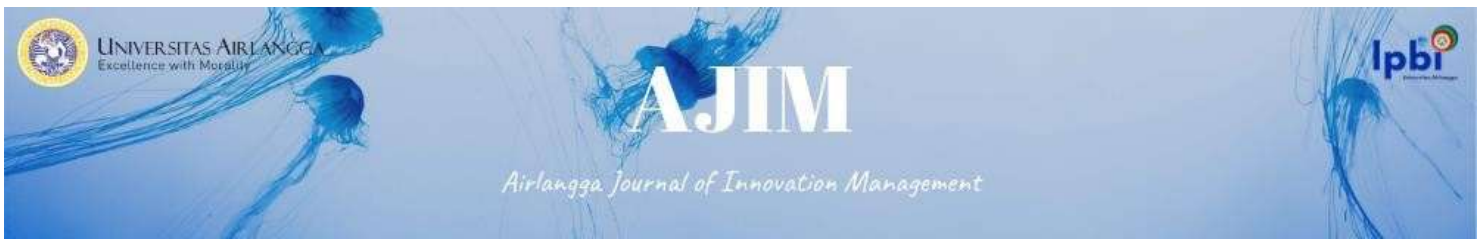

https://journals.sagepub.com/doi/abs/10.1177/1461444814558913.

Kuti, M., Bedő, Z., \& Geiszl, D. (2017) Equity-based Crowdfunding. Financial and Economic Review, 16(4), pp.187-200.

Mas Rahmah. (2019) Hukum Pasar Modal. Jakarta: Kencana.

MUKLIS, F. (2016) Perkembangan Dan Tantangan Pasar Modal Indonesia. Jurnal Al Masraf (Jurnal Lembaga Keuangan dan Perbankan, 1(1),pp. 65-75.

Nasution, Y.S.J. (2015) Peranan Pasar Modal Dalam Perekonomian Negara. Jurnal Human Falah, 2(1), pp.95-112.

Norita, N \& Harahap, D. Penerapan Hukum Pasar Modal Dalam Kegiatan Penawaran Saham Menggunakan

Layananequity-Based Crowdfunding

(Studi

Komparatif Dengan Negara Malaysia), diakses pada tanggal 18 Mei

2020, https://hkhpm.com/wp- content/uploads/2019/03/Deborah-Harahap_NaomiNorita_AILRC2019_FH_UniversitasIndonesia.pdf.

Nugroho, A.Y \& Rachmaniyah, F. (2019) Fenomena Perkembangan Crowdfunding Di Indonesia. Jurnal EkoNika, 4(1), pp.34-46.

Pramana , I.W.B. (2018) Peran Otoritas jasa Keuangan dalam Mengawasi Lembaga Keuangan Non Bank Berbasis Financial Technology Jenis Peer to Peer Lending. Jurnal Kertha Semaya, 6(3), pp. $44-58$.

Pranita, N.K.P \& Suardana, I.W. (2019) Perlindungan Hukum Terhadap Nasabah Pengguna Layanan Fintech (Financial Technology). Jurnal Kertha Semaya, 7(2),pp.1-16.

Valanciene, L., \& Jegeleiciute, S. (2014). Crowdfunding for creating value: stakeholder approach. Precedia-Social and Behavioral Sciences, pp.599-604. 